3. Campbell, M., Neill, C. \& Susman, S. The prognosis of atrial septal defect. Br Med J 1957, 2: 1375.

4. Lani, F., Cipriani, L., Cocchi, A., Zuccala, G. \& Carbonin, P. Ostium secundum atrial septal defect in the elderly. $J$ Am Geriat Soc 1991, 39: 60-63.

\section{Survival without atrial septal defect repair}

Sir,

I read with interest the report by Speechly-Dick et al.' on the long-term surgical outcome of secundum atrial septal defect repair. The association of mitral valve prolapse and atrial septal defect is an interesting one, although the exact cause-and-effect relation is not well understood. The most likely explanation is the altered relation between the size of the left ventricle and that of the mitral valve apparatus in secundum atrial septal defect. ${ }^{2}$ Owing to the left-to-right atrial shunt in atrial septal defect, less blood enters the left ventricle than the right ventricle. Consequently, the left ventricle in subjects with an atrial septal defect tends to be underdeveloped. When the mitral valve becomes relatively 'too big' to be accommodated by the 'small' left ventricle during systole, mitral valve prolapse ensues. ${ }^{2}$ When one waits too long before repairing the atrial septal defect, mitral valve prolapse and the accompanying mitral regurgitation may become irreversible.

Another reason why atrial septal defect once diagnosed should be repaired as early as possible is the risk of atrial fibrillation which is a common late complication of atrial septal defect. ${ }^{3}$ Once atrial fibrillation develops in patients with atrial septal defect, it is usually permanent, as was well shown by Speechly-Dick et al. who reported that atrial fibrillation persisted postoperatively in all of their patients with the arrhythmia preoperatively. The association of atrial fibrillation and stroke is a distinct risk which threatens the long-term prognosis of patients with atrial septal defect, ${ }^{3}$ and lifelong anticoagulant therapy is indicated. ${ }^{4}$

Although operative mortality in surgical repair of secundum atrial septal defect is extremely low, it is not negligible, being $3.3 \%$ in the best hands. ${ }^{5}$ Furthermore, patients undergoing surgical repair of atrial septal defect must consider the extended hospital stay and expense, the need for blood, and all the morbidity and psychological trauma associated with open heart surgery. Fortunately, there is now on the horizon a non-surgical method of closure of atrial septal defect by means of transcatheter delivery of an umbrella device. ${ }^{6,7}$ This non-surgical technique is not only feasible but also promising, provided patients are properly selected. ${ }^{7}$ With increasing experience and longer follow-up, transcatheter closure may well become the standard of care for most patients with secundum atrial septal defects. ${ }^{8}$

Tsung $\mathrm{O}$. Cheng George Washington University Medical Center, 2150 Pennsylvania Avenue NW, Washington DC 20037, USA.

\section{References}

1. Speechly-Dick, M.E., John, R., Pugsley, W.B., Sturridge, M.F. \& Swanton, R.H. Secundum atrial septal defect repair: long-term surgical outcome and the problem of the late mitral regurgitation. Postgrad Med J 1993, 69: 912-915.
2. Cheng, T.O. Mitral valve prolapse. Dis Month 1987, 33: $481-534$.

3. Cheng, T.O. Early thromboembolism following atrial septal defect repair. J Thorac Cardiovasc Surg 1990, 99: 758.

4. Cheng, T.O. Atrial fibrillation, stroke and antithrombotic treatment. Am Heart J 1994, 127: 961-968.

5. Murphy, J.G., Gersh, B.J, McGoon, M.D. et al. Long-term outcome after surgical repair of isolated atrial septal defects. Follow-up at 27 and 32 years. $N$ Engl J Med 1990, 323: 1645-1650.

6. Cheng, T.O. Impending paradoxical embolism: a rare but important diagnosis. Br Heart J 1991, 66: 258.

7. Cheng, T.O. The natural course of atrial septal defect in adults - a still unsettled issue. Clin Invest 1992, 70: 85.

8. Rocchini, A.P. Transcatheter closure of atrial septal defects. Past, present, and future. Circulation 1990, 82: 1044-1045.

\section{Idiopathic cranial diabetes insipidus associated with idiopathic hypoparathyroidism}

\section{Sir,}

We report a case of idiopathic cranial diabetes insipidus associated with idiopathic hypoparathyroidism. With one exception,' this clinical association has not been reported as a component of the autoimmune polyglandular syndrome.

A 20 year old student presented with a history of polyuria, polydipsia, nocturia and nocturnal enuresis since childhood. He was born of a full-term normal pregnancy through vaginal delivery and there were no perinatal complications. There was no past history of head injury or family history of significance.

On examination, he was slim with an arm span of 71 inches and height of 68 inches. His weight was $50.0 \mathrm{~kg}$. There was no abnormality noted on respiratory, cardiovascular, abdominal or neurological examination. Examination of the eyes and fundi was normal. There was no anosmia.

On 24 hours observation, his oral intake of fluids was 7.0 litres and urine output was 6.0 litres. Basal investigation showed haemoglobin $12.3 \mathrm{~g} / \mathrm{dl}$, serum sodium $139 \mathrm{mmol} / \mathrm{l}$, potassium $3.7 \mathrm{mmol} / \mathrm{l}$, creatinine $63 \mathrm{mmol} / \mathrm{l}$, calcium $1.9 \mathrm{mmol} / 1$ (normal range: $2.15-2.62$ ), phosphorus $1.63 \mathrm{mmol} / \mathrm{l}(0.86-1.53)$, alkaline phosphatase $103 \mathrm{IU} / \mathrm{l}$ and albumin $38 \mathrm{~g} / \mathrm{l}$.

Basal endocrine investigations showed serum thyroxine $138.8 \mathrm{nmol} / 1$, tri-iodothyronine $1.93 \mathrm{nmol} / 1$, thyroid stimulating hormone (TSH) $0.6 \mathrm{IU} / \mathrm{l}$, follicle stimulating hormone (FSH) $9.4 \mathrm{IU} / 1$, luteinizing hormone (LH) $3.4 \mathrm{IU} / 1$, testosterone $8.0 \mathrm{nmol} / 1$ (9.6-38.2), cortisol $0900 \mathrm{hrs} 320 \mathrm{mmol} / 1$, growth hormone $5.0 \mathrm{IU} / \mathrm{ml}$ $(<1.0-7.0)$, serum parathyroid hormone $4.7 \mathrm{pmol} / \mathrm{l}$ $(0-5.6)$. To evaluate polyuria and polydipsia, a short water deprivation test was performed. After 5 hours of water deprivation, his serum osmolality rose from 293 to $299 \mathrm{mosmol} / \mathrm{kg}$ and the urine osmolality from $74 \mathrm{mosmol} / \mathrm{kg}$ to $182 \mathrm{mosmol} / \mathrm{kg}$; then he was given DDAVP (desmopressin) $1 \mu \mathrm{g}$ subcutaneously and the urine osmolality rose to $268 \mathrm{mosmol} / \mathrm{kg}$. These results are consistent with a diagnosis of cranial diabetes insipidus. A high resolution computed tomographic scan of the pituitary fossa did not reveal any space-occupying lesion in hypothalamus or pituitary region. He was treated with $10 \mu \mathrm{g}$ desmopressin twice a day intranasally and is doing well with no polyuria or nocturia. 